\title{
Potential reactivity of granitic rocks. Petrographic characterization vs accelerated expansion tests
}

\section{Reatividade potencial de rochas graníticas. Petrografia vs ensaios de expansão}

V. RAMOS a

violetaramos@fc.up.pt

I. FERNANDES a, b mifernandes@fc.ul.pt

A. S. SILVA C

ssilva@Inec.pt

D. SOARES c

dsoares@Inec.pt

F. NORONHA a, fmnoronh@fc.up.pt

\begin{abstract}
Several cases of alkali-silica reaction involving granitic aggregates have been diagnosed in damaged concrete structures in Portugal. Nonetheless, this kind of rock is usually regarded as slow/late reactive or even non-reactive to alkalis. Granitic rocks are widely exploited in Northern and Central Portugal, representing almost half of the produced aggregates in this country. Project IMPROVE rose from the need to accurately diagnose the potential reactivity of granites to alkalis. The study involved about forty granites collected from different regions in Portugal, from which the results of eight samples are being presented in this paper. The tests carried out include the petrographic analyses of the aggregates and mortar and concrete expansion tests. It was concluded that the content of microcrystalline quartz correlates better with the results of AAR-4.1 than with the other expansion tests.
\end{abstract}

Keywords: alkali-silica reaction; granites; petrography; expansion tests; performance.

\section{Resumo}

Diversos casos de reação álcalis-sílica têm sido diagnosticados em estruturas de concreto nas quais foram utilizadas rochas graníticas. No entanto, este tipo de rocha é geralmente considerado como inócuo ou de reactividade pouco provável aos álcalis. As rochas graníticas são amplamente exploradas no norte e centro de Portugal, representando quase metade da produção total de agregados no país. O Projeto IMPROVE surgiu da necessidade de diagnosticar corretamente a potencial reatividade aos álcalis de granitos. No âmbito desse projeto foram estudadas diversas amostras colhidas em diferentes regiões de Portugal, apresentando-se neste artigo os resultados de oito destas. Os ensaios realizados incluem a caracterização petrográfica dos agregados e ensaios de expansão de barra de argamassa e prisma de concreto. Concluiu-se que o conteúdo em quartzo microcristalino se correlaciona melhor com os resultados do ensaio em prisma de concreto RILEM AAR-4.1 do que com os outros ensaios de expansão.

Palavras-chave: reação álcalis-sílica, granito, petrografia, ensaios de expansão, desempenho.

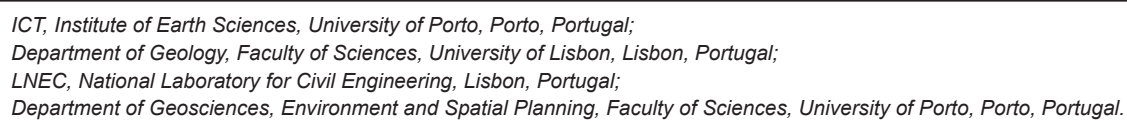




\section{Introduction}

The alkali-aggregate reaction, which comprises the alkali-silica reaction (ASR) and the alkali-carbonate reaction, is a chemical reaction developed between the reactive constituents of the aggregates and the hydroxyl ions associated with alkalis sodium and potassium present in the interstitial solution of concrete. The first statements that ASR in quartz-bearing rocks was a consequence of this mineral's defective lattice emerged in the middle of the last century [1]. In 60's and 70's, several studies were published displaying an attempt to correlate the undulatory extinction angle of quartz crystals and the deformation degree of this mineral's lattice [2,3], being this parameter used in several investigations in order to assess the potential reactivity of aggregates to alkalis [4]. Later on, it was verified that quartz grains showing high undulatory extinction angles were usually associated to the presence of microcrystalline quartz $(<100$ $\mu \mathrm{m})[5]$ which presented a significant solubility due to an increased specific area. This parameter was then considered the most important one in the assessment of the potential reactivity of quartz bearing aggregates. After the observation of deformed Brazilian aggregates rich in quartz, Tiecher et al. [6] concluded that rocks mainly composed by quartz grains with a well-marked undulatory extinction and deformation bands are highly prone to the development of ASR. Other studies showed the existence of a positive correlation between the microcrystalline quartz content, which resulted from the conversion of a crystal into an agglomeration of small crystals in response to deformation, and the results of laboratory mortar and/or concrete expansion tests $[7,8,9]$. Shayan [10] had already attributed the development of ASR to the presence of microcrystalline quartz, affirming that the reaction occurs in the limits of the grains in zones that contain finely subgrained quartz and with a larger surface area. Wigum [11] proposed a new approach for the quantification of the average surface area of quartz crystals in cataclastic rocks through the measurement of the sizes of the aforementioned crystals allowing the estimation of the percentage of microcrystalline quartz present in the rocks. The presence of myrmekites, defined as vermicular intergrowths of quartz and plagioclase, and which is rather frequent in deformed granitic rocks, was also taken into account by Wigum [11] as a preferential silica form for the development of ASR.

Although granitic aggregates are generally regarded as innocuous or of unlikely reactivity to alkalis [12], several papers in the literature testify that granitic rocks can behave, in some parts of the world, as reactive. In Portugal are daily produced high quantities of granitic aggregates which have been used in the construction of important concrete structures and several cases of ASR involving this type of aggregates were diagnosed and investigated
$[13,14]$. As so, the characterization of granitic aggregates reveals itself of major importance. The behaviour of Portuguese granitic aggregates towards ASR is complex in nature and the current assessment methodologies are not totally satisfactory. Therefore, the present study aimed not only to predict the behaviour of granitic aggregates when these are used as aggregates for concrete, but also to establish which laboratory tests best reproduces the performance of the aggregates when used in structures.

\section{Materials and experimental program}

Under the scope of project IMPROVE (Improvement of performance of aggregates in the inhibition of alkali-aggregate reactions in concrete), this paper presents the results of the investigation of eight granitic aggregates exploited in distinct active quarries in northern and central Portugal. According to the nomenclature established by the aforementioned project, samples are referred as GR1, GR2, GR3, GR7, GR17, GR18, GR19 and GR20.

The assessment of the granitic aggregates was carried out by petrographic analysis followed by accelerated expansion tests, namely the accelerated mortar-bar test at $80^{\circ} \mathrm{C}$ and the concrete prism tests at $60^{\circ} \mathrm{C}$ and $38^{\circ} \mathrm{C}$. For this purpose, around $100 \mathrm{~kg}$ of crushed aggregates from different sizes were collected from each quarry and hand samples were selected to produce $25^{\star} 35^{\star} 0.03$ $\mathrm{mm}$ thin-section.

\subsection{Petrographic characterization}

The thin-sections were studied using a polarizing microscope Olympus BX60, coupled with an automatic point counter PELCON (version 01) and a photographic camera Olympus DP 20, available at the National Laboratory for Civil Engineering (LNEC). The assessment of the potential reactivity to alkalis followed the methodology in RILEM AAR-1.1 [15] (Class I - very unlikely to be alkali-reactive; Class II: alkali-reactivity uncertain; Class III: very likely to be alkali-reactive (aggregates containing opal or opaline silica)) and was based in the quantification of microcrystalline quartz $(<100 \mu \mathrm{m})$, including the presence of myrmekites, and in the measurement of the undulatory extinction angle of quartz crystals according to the procedure described in DeHills and Corvalán [2] following the classification expressed in the Portuguese specification LNEC E 415 [16].

\subsection{Accelerated expansion tests}

Aggregates were crushed, sieved and weighed according to the requirements in ASTM C 1260 [17], RILEM AAR-4.1 [18] and RILEM AAR-3 [18]. The tests were conducted at LNEC. [Table 1]

\section{Table 1 - Characteristics of the mixes used in accelerated expansion tests}

\begin{tabular}{|ccccc}
\hline Test & Cement/aggregate & Water/cement & \multicolumn{2}{c}{ Cement } \\
\hline ASTM C 1260 & 0.44 & 0.47 & Type & $\mathrm{Na}_{2} \mathrm{O}_{\text {eq }}(\%)$ \\
RILEM AAR-4.1 & 0.25 & 0.45 & CEM I 42,5 R & $0.86-0.89$ \\
RILEM AAR-3 & 0.25 & 0.45 & CEM I 42,5 R & 0.89 \\
\hline
\end{tabular}


presents the mixes characteristics that were used for mortar-bar and concrete manufacture. For the interpretation of the AAR-4.1 test results, criteria in RILEM AAR-0 [18], Lindgård et al. [19] and LNEC E 461 [20] were used.

\section{Results and discussions}

\subsection{Petrographic characterization}

The results of petrographic characterization are summarized in [Table 2]. Taking into account the percentages of microcrystalline quartz in each of the aggregates, only aggregates GR1, GR2 and GR18 present percentages of microcrystalline quartz above 2.0 vol.\%, being classified according to RILEM AAR-1.1 [15] and to the Portuguese specification LNEC E 461 [20] as Class II (potentially reactive). All other aggregates are classified as non-reactive (Class I). Some textural and petrographic aspects of the investigated granitic aggregates are displayed in [Figure 1].

\subsection{Accelerated expansion tests}

The results of the accelerated expansion tests ASTM C 1260,
RILEM AAR-4.1 and RILEM AAR-3 are displayed in [Figures 2A, $2 \mathrm{~B}$ and $2 \mathrm{C}$ ], respectively.

[Figure 2A] shows that all aggregates present in ASTM C 1260 at fourteen days expansion values below $0.10 \%$. According to the interpretation criterion in ASTM C 1260 [17], these results are indicative of aggregates with a non-reactive behaviour. The test period was extended till twenty-eight days [21], confirming that all aggregates are classified as non-reactive. This is supportive of the Portuguese specification LNEC E 461 [20] on the usefulness of the accelerated mortar-bar test concerning the assessment of the potential alkali-reactivity of granitic aggregates. Even so, aggregates GR2, GR18 and GR20 were the ones that showed the highest expansions $(0.10 \%, 0.10 \%$ and $0.08 \%$, respectively). It should be noted that, at the end of the test, a plateau of the expansion curves is not achieved for any of the aggregates. As suggested by Santos Silva et al. [22], the extension of the test period till 100 days using a threshold expansion of $0.20 \%$, should be carried out.

Concerning RILEM AAR-4.1 [Figure 2B], the interpretation criteria vary both in the threshold of reactivity and in the duration of the test. According to the criterion in LNEC E 461 [20] (0.02\% at twelve weeks) it is possible to verify that aggregates GR1, GR7 and GR19 are the ones to be considered as non-reactive. On the other hand,

\section{Table 2 - Results of the petrographic characterization of the investigated granitic aggregates}

\begin{tabular}{|c|c|c|c|}
\hline Aggregate & Brief petrographic description & $\begin{array}{l}\text { Undulatory extinction angle }\left({ }^{\circ}\right) \\
\text { of quartz crystals (mean) and } \\
\text { respective class* }\end{array}$ & $\begin{array}{l}\text { Potentially reactive silica forms } \\
(<100 \mu \mathrm{m})(\text { vol. } \%) \\
\text { and reactivity class }\end{array}$ \\
\hline GR1 & $\begin{array}{l}\text { Medium-grained granite with porphyritic } \\
\text { tendency. Frequent microcracks, especially } \\
\text { in quartz and plagioclase crystals, filled by } \\
\text { microcrystalline muscovite and oxides. }\end{array}$ & $\begin{array}{l}16.0 \\
\text { Moderate }\end{array}$ & $\begin{array}{l}\text { Quartz inclusions; } \\
\text { myrmekites } \\
2.4 \text { Class II }\end{array}$ \\
\hline GR2 & $\begin{array}{l}\text { Coarse to medium-grained porphyritic } \\
\text { granite with deformation evidences. }\end{array}$ & $\begin{array}{l}20.0 \\
\text { Moderate }\end{array}$ & $\begin{array}{l}\text { Tectonized quartz; } \\
\text { quartz inclusions; } \\
\text { myrmekites } \\
21.7 \text { Class II }\end{array}$ \\
\hline GR3 & $\begin{array}{l}\text { Coarse to medium-grained porphyritic } \\
\text { granite with abundant microcracks filled by } \\
\text { oxides and microcrystalline muscovite. }\end{array}$ & $\begin{array}{l}18.0 \\
\text { Moderate }\end{array}$ & $\begin{array}{l}\text { Quartz inclusions; } \\
\text { myrmekites } \\
1.0 \text { Class I }\end{array}$ \\
\hline GR7 & $\begin{array}{l}\text { Coarse to medium-grained } \\
\text { porphyritic granite }\end{array}$ & $\begin{array}{l}14.0 \\
\text { Weak }\end{array}$ & $\begin{array}{l}\text { Myrmekites } \\
0.1 \text { Class I }\end{array}$ \\
\hline GR17 & Medium to fine-grained granite. & $\begin{array}{l}15.0 \\
\text { Moderate }\end{array}$ & $\begin{array}{l}\text { Quartz inclusions; } \\
\text { myrmekites } \\
1.5 \text { Class I }\end{array}$ \\
\hline GR18 & $\begin{array}{l}\text { Medium-grained porphyritic granite } \\
\text { with deformation evidences. }\end{array}$ & $\begin{array}{l}23.0 \\
\text { Moderate }\end{array}$ & $\begin{array}{l}\text { Tectonized quartz; } \\
\text { quartz inclusions; } \\
\text { myrmekites } \\
4.8 \text { Class II }\end{array}$ \\
\hline GR19 & $\begin{array}{l}\text { Medium-grained granite. } \\
\text { Presence of abundant microcracks. }\end{array}$ & $\begin{array}{l}20.0 \\
\text { Moderate }\end{array}$ & $\begin{array}{l}\text { Quartz inclusions; } \\
\text { myrmekites } \\
\text { 1.4 Class I }\end{array}$ \\
\hline GR20 & $\begin{array}{l}\text { Medium to fine-grained granite. } \\
\text { Presence of abundant microcracks. }\end{array}$ & $\begin{array}{l}19.0 \\
\text { Moderate }\end{array}$ & $\begin{array}{l}\text { Quartz inclusions; } \\
\text { myrmekites } \\
1.2 \text { Class I }\end{array}$ \\
\hline
\end{tabular}


according to RILEM AAR-0 [18] (0.03\% at fifteen weeks), besides the aforementioned aggregates, GR3 and GR18 are also regarded as non-reactive, whilst the criterion in Lindgård et al. [19] $(0.03 \%$ at twenty weeks) considers only GR1 and GR7 as non-deleterious. However, it can be verified that after twenty-weeks no aggregate exhibits a leveling-off of its expansion curve.

According to RILEM AAR-0 [18], results below $0.05 \%$ at one year in RILEM AAR-3, [Figure 2C] indicate non-reactive aggregates, whilst results above $0.10 \%$ indicate reactive aggregates. For values between $0.05 \%$ and $0.10 \%$ there is not an agreement towards the most adequate interpretation. In this case, the criterion established in LNEC E 461 [20] was followed for which, according to the Portuguese experience, an expansion above $0.05 \%$ at one year is sufficient to regard an aggregate as potentially reactive. That is the case of GR2 which presents a final expansion value of $0.06 \%$, though without achieving a plateau of expansion. Regarding all the other aggregates, their final expansion values are below $0.05 \%$, which classifies them as non-reactive. Among those aggregates, only the expansion of GR7 seems to have leveled-off.

\subsection{Petrographic characterization vs accelerated expansion tests}

[Table 3] summarizes the results achieved for the investigated aggregates when tested using the different methodologies.

According to the petrographic characterization, only aggregates GR1, GR2 and GR18 present percentages of microcrystalline quartz above 2.0 vol. \%, which classify them as Class II according to RILEM AAR-1.1 [15] and LNEC E 461 [20,23]. Aggregate GR2 is clearly the one that presents a higher volume of microcrystalline quartz, followed by GR18 and GR1. As so, GR3, GR7, GR17, GR19 and GR20 can be classified as Class I. However, according to the Portuguese experience and also due to the variation of the characteristics of these aggregates inside a single quarry, the approach of the specification in LNEC E 461 [20] is conservative and demands the use of expansion tests in order to complement the petrographic characterization.

As shown in [Figure 3], there is a positive but moderate correlation between the percentage of microcrystalline quartz and the undulatory extinction angle $(r=0.41)$. For example, aggregate GR2 clearly shows the highest content of microcrystalline quartz, but it is aggregate GR18 that displays the highest undulatory extinction angle of quartz crystals. Nonetheless, both aggregates are equally classified as Class II by the petrographic characterization. Furthermore, aggregate GR19, which is regarded as Class I, shows a similar undulatory extinction angle to aggregate GR2, but a much lower content of microcrystalline quartz in comparison to the later aggregate. The aggregates that display the lowest undulatory extinction values seem to establish a better correlation with the percentages of microcrystalline quartz, being plotted closer to the regression line. Such conclusions seem to be supported by the work of West $[24,25]$, who pointed the undulatory extinction angle as only a possible indicator of the potential reactivity of the aggregates to alkalis.

The comparison between the results of the petrographic characterization and of ASTM C 1260 allows verifying that this test does not sustain the results of the petrographic analysis in what concerns aggregates GR1, GR2 and GR18, classifying all granitic

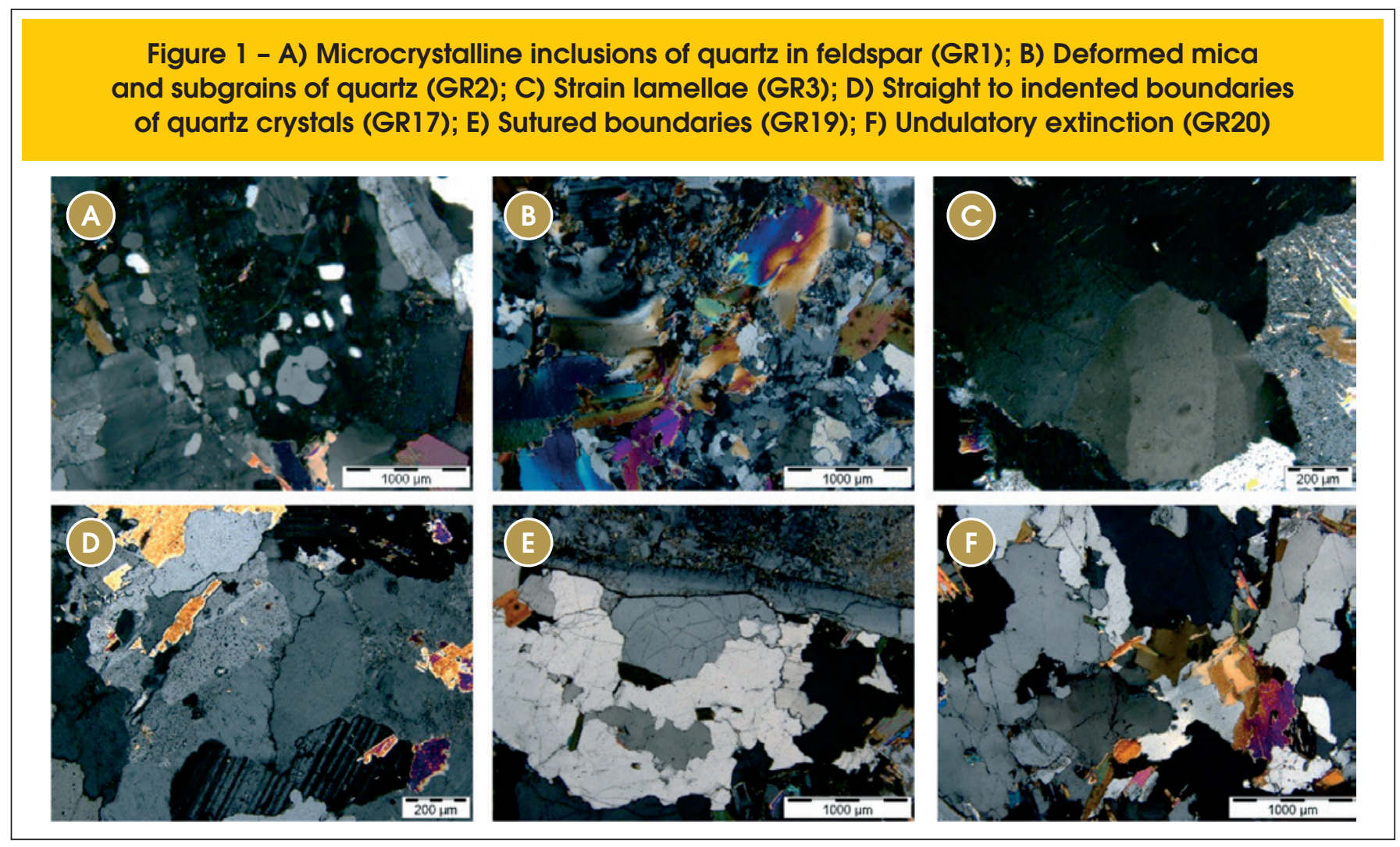


Figure 2 - Expansion curves: A) ASTM C 1260; B) RILEM AAR-4.1; C) RILEM AAR-3 (the dotted lines indicate the thresholds suggested by the considered authors)

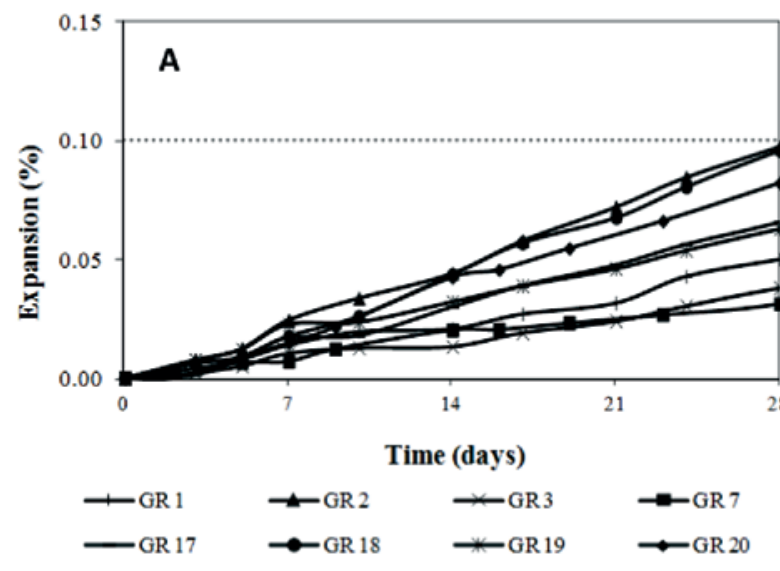

.... RILEM AAR-0 [18] and Santos Silva and Braga Reis [21]

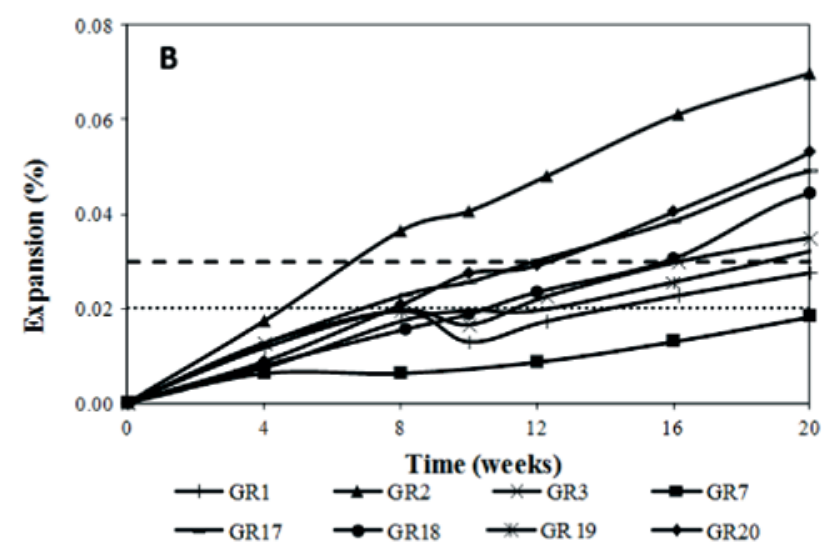

- - RILEM AAR-0 [18] and Lindgaird et al. [19] -...-LNEC E $461[20]$

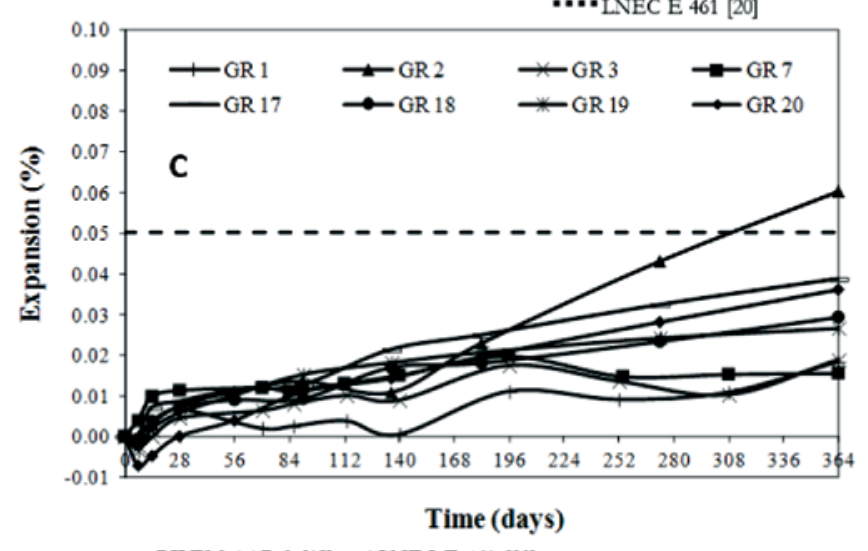

- -RILEM AAR-0 [18] and LNEC E 461 [20]

Table 3 - Summary of the results achieved in the different methodologies used for the assessment of the potential reactivity of the granitic aggregates

\begin{tabular}{|c|c|c|c|c|c|c|c|c|c|}
\hline Method & Criteria & GR1 & GR2 & GR3 & GR7 & GR17 & GR18 & GR19 & GR20 \\
\hline \multirow{4}{*}{$\begin{array}{c}\text { Petrographic } \\
\text { characterization }\end{array}$} & RILEM AAR-1.1 (15) & Class II & Class II & Class I & Class I & Class I & Class II & Class I & Class I \\
\hline & LNEC E 461 (20) & Class II & Class II & Class I & Class I & Class I & Class II & Class I & Class I \\
\hline & Microcrystalline quartz (vol.\%) & 2.4 & 21.7 & 1.0 & 0.1 & 1.5 & 4.8 & 1.4 & 1.2 \\
\hline & Undulatory extinction & Mod. & Mod. & Mod. & Weak & Mod. & Mod. & Mod. & Mod. \\
\hline \multirow[b]{2}{*}{ ASTM C 1260} & RILEM AAR-0 (18) & NR & NR & NR & NR & NR & NR & NR & NR \\
\hline & $\begin{array}{c}\text { Santos Silva } \\
\text { and Braga Reis (21) }\end{array}$ & NR & NR & NR & NR & NR & NR & NR & NR \\
\hline \multirow{3}{*}{ RILEM AAR-4. 1} & LNEC E 461 (20) & NR & PR & PR & NR & PR & PR & NR & PR \\
\hline & RILEM AAR-0 (18) & NR & PR & NR & NR & PR & NR & NR & PR \\
\hline & Lindgård et al. (19) & NR & PR & PR & NR & PR & PR & PR & PR \\
\hline RILEM AAR-3 & $\begin{array}{l}\text { RILEM AAR-0 (18) } \\
\text { and LNEC E } 461 \text { (20) }\end{array}$ & NR & PR & NR & NR & NR & NR & NR & NR \\
\hline
\end{tabular}


aggregates as non-reactive. Although this accelerated expansion test is worldwide used in the assessment of aggregates for concrete, it is still not well recognized that its limits correspond to the reactivity of some of the slow reactive aggregates, being these classified as false non-reactive [26], which is certainly the case of aggregates GR2 and GR18. The Portuguese experience has shown that this test is not suitable when applied to granitic aggregates and, as so, it is considered as inadequate for the evaluation of the potential reactivity of this type of rocks [14]. A possible explanation for these results can be related to the crushing process to obtain the very fine fractions needed for ASTM C 1260, which can destroy the original microstructure of the rocks, leading to an underestimation of their reactivity in accelerated mortar-bar tests $[27,28]$.

From the comparison between the results of RILEM AAR-4.1 and of the petrographic characterization, it is possible to verify that: the interpretation criteria used at twelve, fifteen and twenty weeks confirm aggregate GR2 as potentially reactive (Class II); aggregate GR18, also classified as Class II, is only considered as nonreactive by the criterion in RILEM AAR-0 [18]; there is agreement in the classification of aggregate GR7 as non-reactive (Class I) according to the different criteria; aggregate GR1, classified as Class II by the petrographic analysis, is classified as non-reactive by all the interpretation criteria; aggregates GR3, GR17, GR19 and GR20, though classified as Class I by the petrographic characterization, are classified as potentially reactive in RILEM AAR4.1 by at least one of the interpretation criteria. For a most correct interpretation of the aforementioned described, it is important to keep in mind that granitic aggregates are regarded as being slowreactive in what concerns the development of ASR. Therefore, it would be more adequate to admit for RILEM AAR-4. 1 the criterion in Lindgård et al. [19], which uses a test period of twenty weeks. In fact, this is one of the criteria that classifies a larger number of granitic aggregates as potentially reactive, even though comprised in the uncertainty band of $0.030 \% \pm 0.010 \%$ defined in Lindgård et al. [19] and RILEM AAR-0 [18]. However, although the criterion in LNEC E 461 [20] uses the lowest expansion limits and a shorter test period (twelve weeks), the interpretation of the aggregates' behaviour in RILEM AAR- 4.1 shows that this criterion is effective in the detection of almost all the aggregates classified as potentially reactive by the criterion in Lindgård et al. [19], which uses a test period of twenty weeks. The potential reactivity detected for aggregates GR3, GR19 and GR20 in RILEM AAR-4.1 can be, probably, justified by the great abundance of microcracks in those aggregates, which was pointed out by Velasco-Torres et al. [29] as the main responsible for the interstitial fluid intake to the siliceous components in the aggregates. The assumption in LNEC E 461 [20] that petrographic characterization is not sufficient for the classification of granitic aggregates seems to be justified, since some potentially reactive behaviours that were observed in RILEM AAR-4.1 were not identified by the petrographic characterization. It should not also be ignored the actual state of knowledge which suggests that other minerals, besides quartz, can have a role in ASR development [30] - ASR products apparently related to feldspars and micas, which are abundant in the investigated rocks, were observed in Portuguese granitic aggregates.

According to Lindgård et al. [19], RILEM AAR-3 is regarded as the most inadequate test for the identification of slow-reactive aggregates. This test was also considered as inconclusive at the end of one year testing period and a larger period might be necessary for the expansions to reach the critical limit considered for this test $[15,26]$. Such conclusion was based on the non-levelling-off of the expansion curves at one year. In this study, this phenomenon occurs for all aggregates, with the exception of GR7. Aggregate GR2 is clearly classified as reactive, but, for all the other aggregates regarded as non-reactive at one year, it should be convenient to

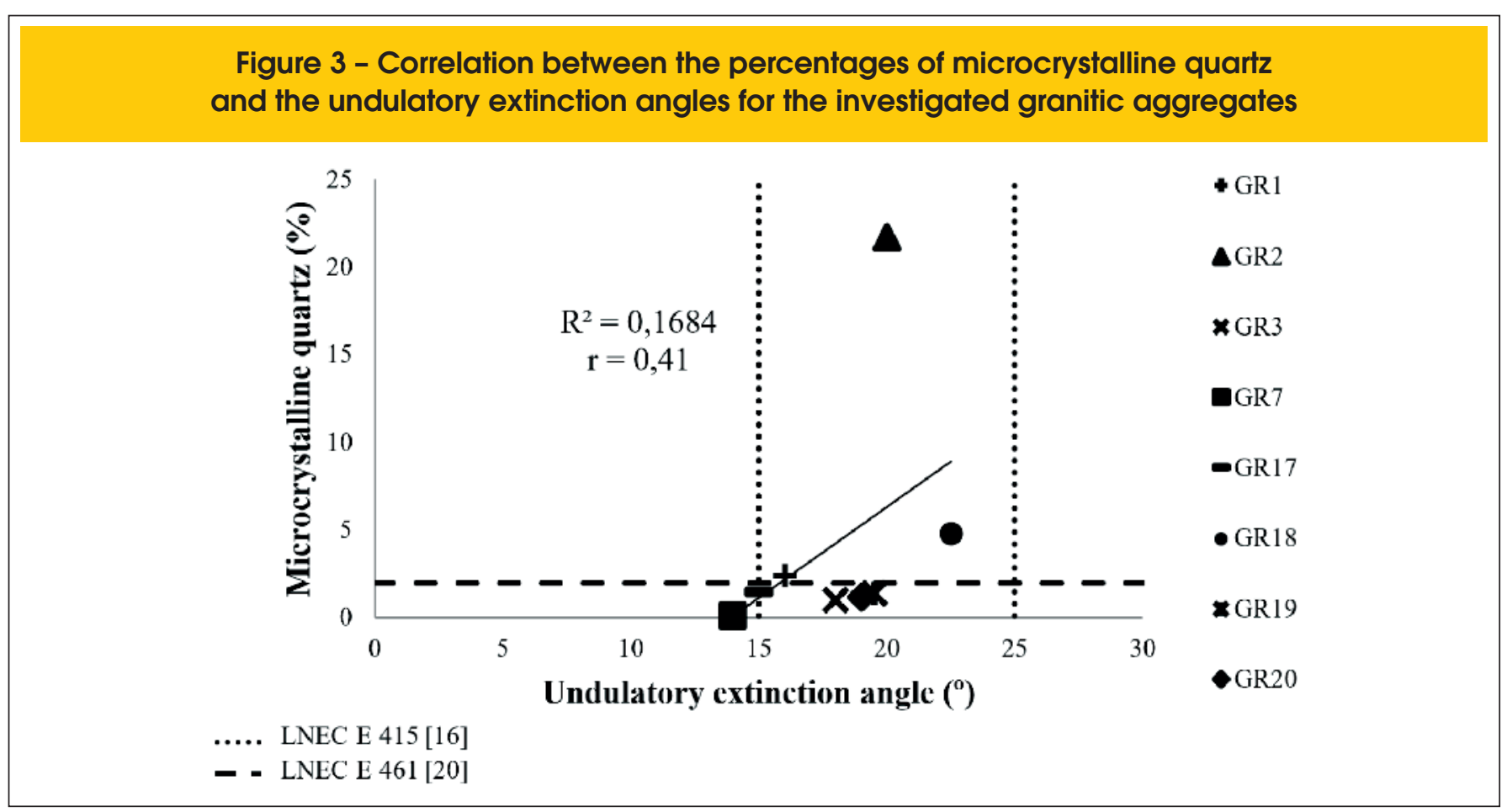


Figure 4 - Correlations between the expansion tests and the percentages of microcrystalline quartz. A) ASTM C 1260 (14 days) vs Microcrystalline quartz; B) ASTM C 1260 (28 days) vs Microcrystalline quartz; C) RILEM AAR-4.1 (12 weeks) vs Microcrystalline quartz; D) RILEM AAR-4.1 (15 weeks) vs Microcrystalline quartz; E) RILEM AAR-4.1 (20 weeks) vs Microcrystalline quartz; F) RILEM AAR-3 (1 year) vs Microcrystalline quartz

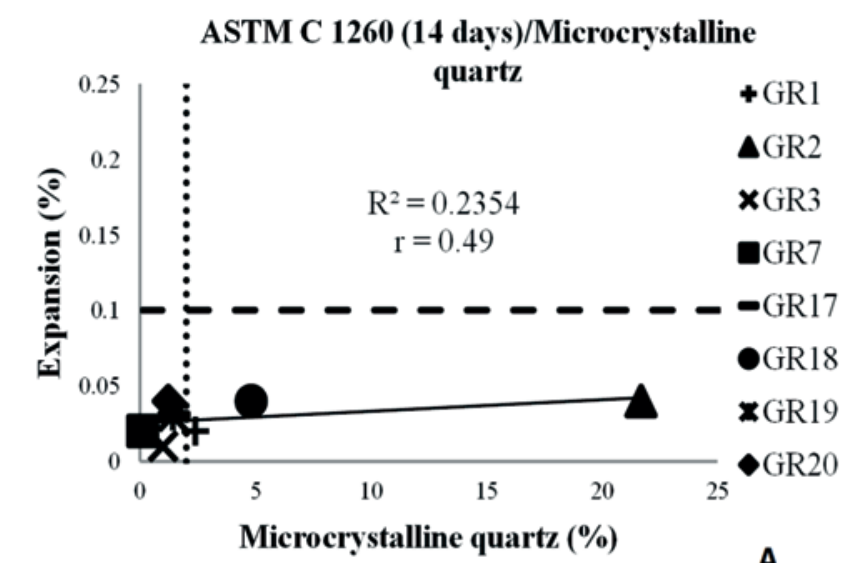

- - RILEM AAR-0 [18]

… LNEC E 461 [20]

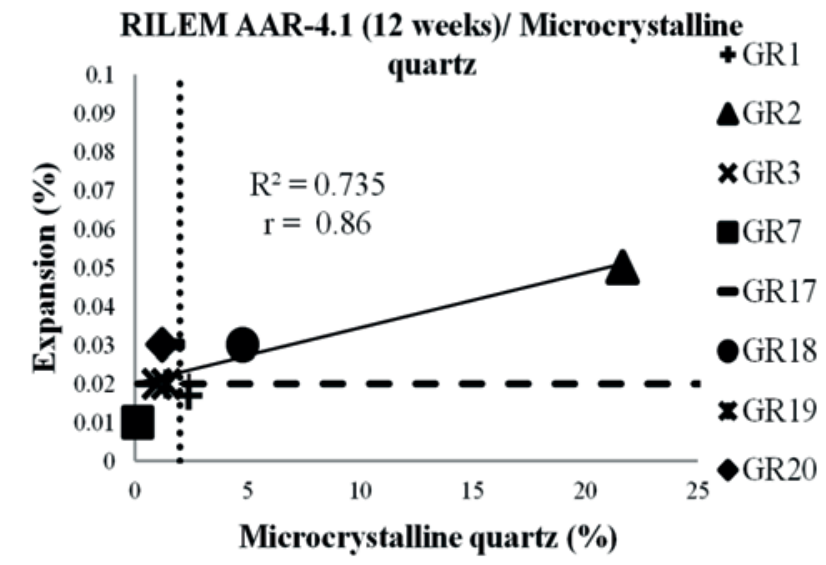

- -LNEC E $461[20]$

…. LNEC E 461 [20]

C

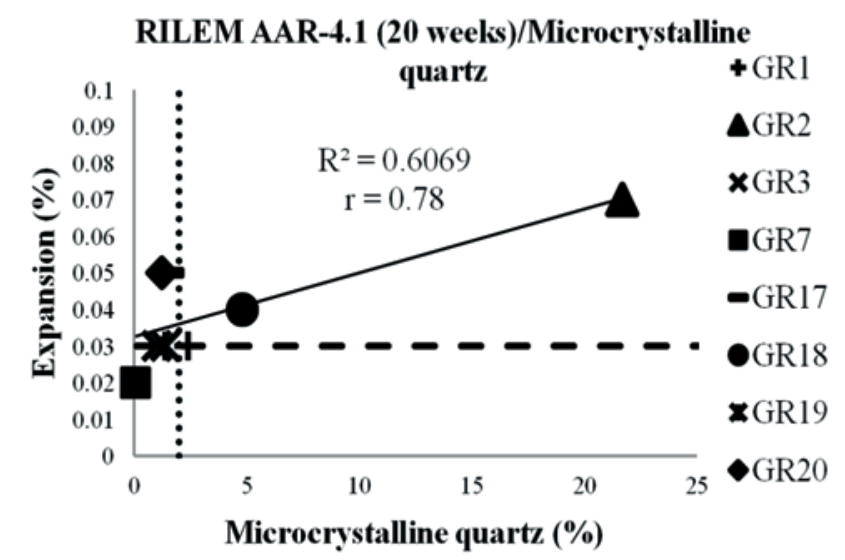

- - Lindgård et al. [19]

.... LNEC E $461[20]$

E

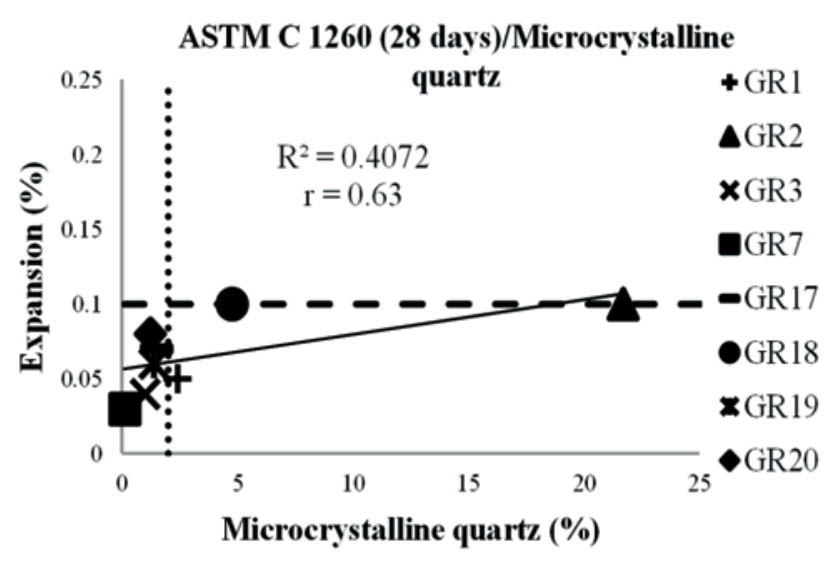

- - Santos Silva e Braga Reis [21]
-...LNEC E 461 [20]

B

RILEM AAR-4.1 (15 weeks)/Microcrystalline

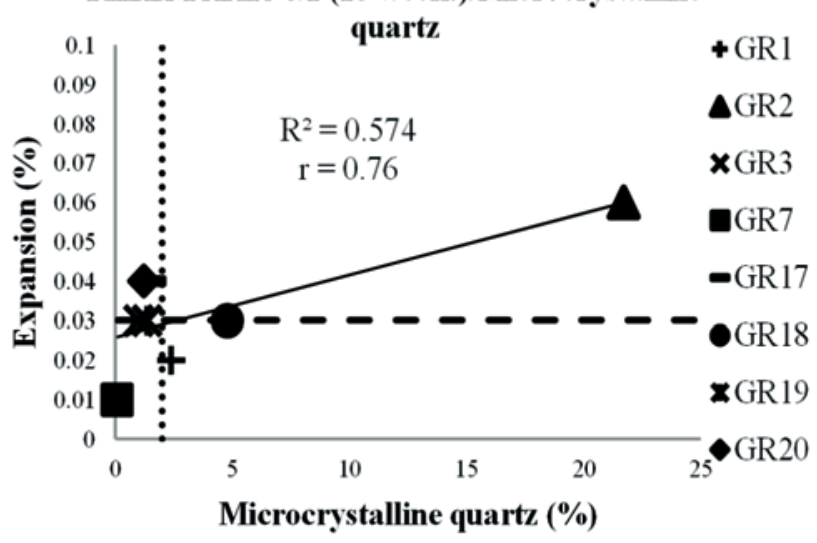

- - RILEM AAR-0 [18]

.... LNEC E 461 [20]

D

RILEM AAR-3 (1 year)/Microcrystalline

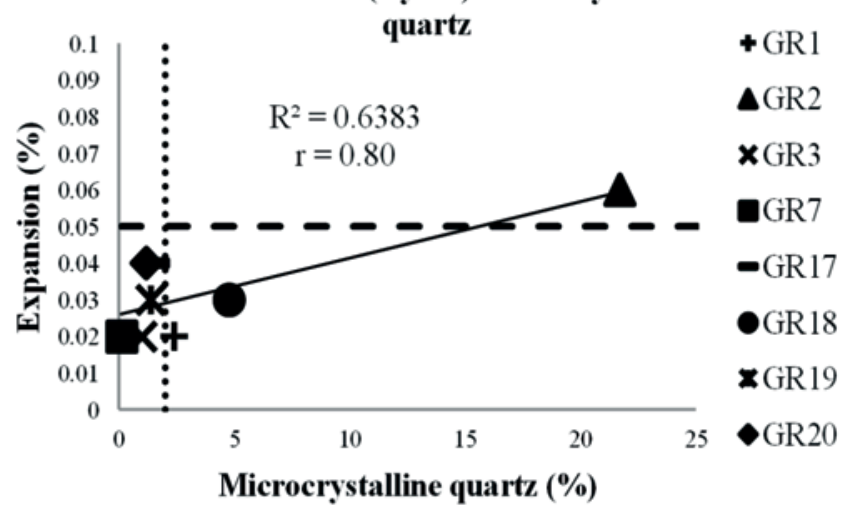


extend the test in order to confirm their behaviours. The obtained results are in agreement with Lindgård et al. [19] in which RILEM AAR-4.1 is more effective than RILEM AAR-3 in the assessment of slow-reactive aggregates, even though this last test uses a lower temperature $\left(38^{\circ} \mathrm{C}\right)$, simulating the real conditions to which concrete structures are exposed. This behaviour is, also, verified in the studied aggregates, which start to expand earlier in RILEM AAR4.1 than in RILEM AAR-3.

[Figure 4] compares the expansions obtained for the granitic aggregates when submitted to the different accelerated expansion tests and their respective interpretation criteria with the percentages of microcrystalline quartz. It is also possible to verify that the strongest correlations occur between the percentages of microcrystalline quartz and the concrete prism tests, especially with RILEM AAR-4.1 when the criterion in LNEC E 461 [20] is used. As for ASTM C 1260, this test shows better correlations at twentyeight days. However, as already noted, this test is not effective in the assessment of the potential reactivity to alkalis of granitic aggregates.

\section{Conclusions}

From the comparison between the results of the petrographic characterization of the investigated granitic aggregates and the different expansion tests to which they were submitted to it is possible to conclude:

- the undulatory extinction angle should only be used as a possible indicator of ASR and not as a diagnostic tool;

- besides the quantification of the microcrystalline quartz, the presence of microcracks should be regarded in the assessment of the aggregates;

there is the possibility that other minerals, besides quartz, can participate in the development of ASR and therefore the evaluation of the weathering degree might be important;

- ASTM C 1260 should never be solely used in the assessment of slow-reactive aggregates; the extension of the test period til 100 days using a threshold expansion of $0.20 \%$, is suggested;

RILEM AAR-4.1 is the test that detects a higher number of potentially reactive aggregates. The use of the criterion in Lindgård et al. is suggested as the most adequate for this type of aggregates.

\section{Acknowledgements}

The authors would like to acknowledge LNEC, ICT and Fundação para a Ciência e Tecnologia (FCT) for the financial support of the Project IMPROVE (Ref: PTDC/ECM/115486/2009) and of the Strategic Project (Ref. PEST-OE/CTE/UI0039/2014). The author $V$. Ramos is grateful to FCT towards the financial support of her PhD studies (Ref: SFRH/BD/47893/2008).

\section{References}

[1] BROWN LS. Some observations on the mechanism of alkaliaggregate reactions. ASTM Bulletin, 1955; 205, 40 p.

[2] DEHILLS SM, CORVALÁN J. Undulatory extinction in quartz grains of some Chilean granitic rocks of different ages. Geological Society of America Bulletin, v.75, 1964; p.363-366.
[3] GOGTE, BS. An evaluation of some common Indian rocks with special reference to alkali-aggregate reactions. Engineering Geology, v.7, 1973; p.135-153.

[4] DOLAR-MANTUANI, LMM. Handbook of concrete aggregates: a petrographic and technological evaluation (Building Materials Science Series): Park Ridge, Noyes Publications, 1983.

[5] GRATTAN-BELLEW PE. Microcrystalline quartz, undulatory extinction \& the alkali-silica reaction. In: Proceedings of the 9th International Conference on Alkali-Aggregate Reaction in Concrete, 1992, London, UK, p.383-394.

[6] TIECHER F, ROLIM PH, HASPARYK NP, MOLIN DCCD, GOMES MEB, GLIEZE P. Reactivity study of Brazilian aggregates through silica dissolution analysis. In: Proceedings of the 14th Conference on Alkali-Aggregate Reaction in Concrete, 2012, Austin, USA, $10 \mathrm{p}$.

[7] KERRICK D, HOOTON, R. ASR of concrete aggregate quarried from a fault zone: results and petrographic interpretation of accelerated mortar bar tests. Cement and Concrete Research, v. 220, 1992; p.949-960.

[8] THOMSON ML, GRATTAN-BELLEW PE, WHITE JC. Application of microscopic and XDR techniques to investigate alkali-silica reactivity potential of rocks and minerals. In: Proceedings of the 16th International Conference on Cement Microscopy, International Cement Microscopy Association, Texas, USA, 1994, $19 \mathrm{p}$.

[9] WENK H-R, MONTEIRO PJM, SHOMGLIN K. Relationship between aggregate microstructure and mortar expansion. A case study of deformed granitic rocks from Santa Rosa myIonite zone. Journal of Materials and Science, v.43, 2008; p.1278-1285.

[10] SHAYAN A. Alkali-reactivity of deformed granitic rocks: a case study. Cement and Concrete Research, v.23, 1993; p.1229-1236.

[11] WIGUM BJ. Examination of microstructural features of Norwegian cataclastic rocks and their use for predicting alkalireactivity in concrete. Engineering Geology, v.40, 1995; p.195-214.

[12] CONCRETE SOCIETY. Concrete petrography: an introductory guide for the non-specialist. Report of a Concrete Society Working Party, Technical Report, v.71, 2010; p.101.

[13] FERNANDES I, NORONHA F, TELES M. Microscopic analysis of alkali-aggregate reaction products in a 50-year-old concrete. Materials Characterization, v.53, 2004; p.295-306.

[14] SANTOS SILVAA. Degradação do betão por reacções álcalis sílica. Utilização de cinzas volantes e metacaulino para a sua prevenção. [Dissertation] Laboratório Nacional de Engenharia Civil and Escola Superior de Engenharia da Universidade do Minho, 2005

[15] RILEM AAR-1.1. Detection of potential alkali-reactivity, Part 1: petrographic examination method for aggregates. In: NIXON PJ and SIMS I (Eds.). RILEM recommendations for the prevention of damage by alkali-aggregate reactions in new concrete structures, State-of-the-art report of the RILEM Technical Committee 219-ACS, RILEM State-of-the-Art Reports, Springer-Dordrecht, Netherlands v. 17, 2016; p. 35-60.

[16] LNEC E 415. Inertes para argamassas e betões - determinação da reactividade potencial com os álcalis. Análise petrográfica. Especificação LNEC, Lisboa, Portugal, 1993; 6 p. 
[17] ASTM C 1260. Standard test method for potential alkali reactivity of aggregates (mortar-bar method). The American Society for Testing and Materials, Philadelphia, USA, 2007; 4 p.

[18] RILEM AAR-0. Outline guide to the use of RILEM methods in the assessment of the alkali-reactivity potential of aggregates. In: NIXON PJ and SIMS I (Eds.). RILEM recommendations for the prevention of damage by alkali-aggregate reactions in new concrete structures, State-of-the-art report of the RILEM Technical Committee 219-ACS, RILEM Stateof-the-Art Reports, Springer-Dordrecht, Netherlands v. 17, 2016; p. 5-34.

[19] LINDGÅRD J, NIXON PJ, BORCHERS I, SCHOUENBORG B, WIGUM BJ, HAUGEN M, ÅKESSON U. The EU "PARTNER" Project - European standard tests to prevent alkali reactions in aggregates: final results and recommendations. Cement and Concrete Research, v. 40, 2010; p.611-635.

[20] LNEC E 461. Betões. Metodologias para prevenir reacções expansivas internas. Especificação LNEC, Lisboa, Portugal, 2007: 6 p.

[21] SANTOS SILVA A, BRAGA REIS MO. Avaliação da reactividade aos álcalis dos agregados para betão. In: Proceedings of the Encontro Nacional de Betão Estrutural, Faculdade de Engenharia da Universidade do Porto, Portugal, 2000; p.23-32.

[22] SANTOS SILVAA, SOARES D, FERNANDES I, CUSTÓDIO J, BETTENCOURT RIBEIRO A. Prevenção das reações álcalis-agregado (RAA) no concreto - melhoria do monitoramento da reatividade aos álcalis de agregados. QUALIS CAPES: Politécnica (Instituto Politécnico da Bahia), v.21, 2014; p.96 -109.

[23] Ramos V. Characterization of the potential reactivity to alkalis of Portuguese aggregates for concrete. [Dissertation] Faculdade de Ciências da Universidade do Porto and Universidade de Aveiro; 2013.

[24] WEST G. A note on undulatory extinction of quartz in granite. Engineering Geology, v.24, 1991; 159-165.

[25] WEST G. Undulatory extinction of quartz in some British granites in relation to age and potential reactivity. Quarterly Journal of Engineering Geology, v.27, 1994; p.69-74.

[26] SHAYAN A. Field evidence for inability of ASTM C $1260 \mathrm{lim}$ its to detect slowly reactive Australian aggregates. Australian Journal of Civil Engineering, v.3, 2007; p.13-26.

[27] LU D, FOURNIER B, GRATTAN-BELLEW PE. Effect of aggregate particles size on determining alkali-silica reactivity by accelerated tests. Journal of ASTM International, v.3, 2006; $11 \mathrm{p}$.

[28] LU D, FOURNIER B, GRATTAN-BELLEW PE. Evaluation of accelerated test methods for determining alkali-silica reactivity of concrete aggregates. Cement and Concrete Composites, v.28, 2006; p.546-554.

[29] VELASCO-TORRES A, ALAEJOS P, SORIANO J. Comparative study of the alkali-silica reaction (ASR) in granitic aggregates. Estudios Geológicos, v.66, 2010; p.105-114.

[30] HAGELIA P, FERNANDES I. On the AAR susceptibility of granitic and quartzitic aggregates in view of petrographic characteristics and accelerated testing. In: Proceedings of the 14th Conference on Alkali-Aggregate Reaction in Concrete, Austin, USA, 2012; 10 p. 